\title{
ИСТОРИЯ И ПРОБЛЕМЫ РАЗВИТИЯ ТУРИЗМА В РЕСПУБЛИКЕ АБХАЗИИ
}

\author{
(C) 2021 Багаутдинова Наиля Гумеровна \\ доктор экономических наук, профессор, Институт управления, экономики и финансов \\ Казанский (Приволжский) федеральный университет, Россия, Казань \\ E-mail: nailya.mail@mail.ru \\ (c) 2021 Адлейба Ада Гивиевна \\ аспирант \\ Казанский (Приволжский) федеральный университет, Россия, Казань \\ E-mail: aadleiba@mail.ru
}

Туризм можно считать той сферой экономики, которая охватывает, как средства размещения, так и транспорт, связь, места питания, развлечений и другое, данная сфера оказывает влияние на каждый субъект. Туризм оказывает большое влияние на экономику каждого субъекта. В работе проведено исследование истории и проблем развития международного туризма в Абхазии, отмечены основные направления развития туризма.

Ключевые слова: туризм, Россия, Республика Абхазия, Грузия, Сухуми, природные условия, транспортная инфраструктура, кадры.

С древних времен Республика Абхазия блистала удивительными целебными местами, завлекала всех в республику и радовала каждого туриста. До настоящего времени около Сухума на реке Беслетка славились минеральные источники, называвшиеся «Счастливые родники» [2]. Книга К.Д. Мачавариани: «Путеводитель по Сухуму и Сухумскому округу», основательно отражает в себе всю природу античной эпохи. Уникальные минеральные источники, по мнению автора, являлись местом, где отдыхали византийские и римские аристократы. Одна из грузинских летописей затрагивает интересные факты о лечебных местах, где описано, что Сухум был той здравницей, куда наведывалась царица Тамара в зимнее и летнее время для отдыха. В 1898 г. на XII Международном съезде врачей, проходившем в Москве, Сухум был удостоен стать курортом, изумительной климатической станцией для людей с заболеванием туберкулез легких. Такому призванию послужили труды профессоров А.А. Остроумова, Ф.Л.Пастернацкого, А.И. Воейкова [1].

В Республике Абхазия в конце XI века, а именно в Сухуми и Гаграх возводились гостиницы и пансионаты. А в 1901 г. в Гаграх принц Ольденбургский взял на себя ответственность за Гагрскую климатическую станцию. А уже через два года 9 января 1903 г. открывали туристическую станцию при министрах и царских особах.

Были сооружены и прекрасно оборудованы мастерские (слесарно-механическая и столярная), построены две мельницы, скотобойня и даже организованна типография [2]. Продавались отдельные распланированные участки с обязательством застройки для заселения Гагр. Участки эти были куплены русской аристократией, которая имела определённый коммерческий расчёт: извлечение большего дохода при меньших затратах. Климатическая станции становилась убыточной, несмотря на то, что здесь были удивительные климатические условия, здоровая и изумительная местность, удобства, которые соответствовали всем потребностям. Долгое время не могла окупить свои расходы и была вынуждена закрыться.

Следующим городом, развивавшимся как курорт, стал Сухум. В городе начали существовать более 20 частных пансионатов в период 1905-1915 гг., наряду с этим открыли 5 частных гостиниц. Огромное вложение в формирование Абхазии как страны, с лечебными функциями, по предназначению лечения больных туберкулезом, привнес Н.Н.Смецкой - крупный фабрикант [4]. В Гульрипше в 1904 г. закончили постройку одного из корпусов санатория Смецкого (второе здание - в 1905 г., третье (крупнее двух предыдущих и вместимостью 600 больных) - в 1913 г. Именно в Гульрипше благодаря Н.Н. Смецкому начал свою работу один из первых санаториев на черноморском побережье [4].

В районах Сухуми, Нового Афона и Гагры 
были туристические маршруты представлявшие собой непроходимые тропы в труднодоступных местах, которые проходили там, где были большие скопления малярии и болот. Отсутствовал обученный персонал, экскурсоводы, гиды-переводчики. Основным транспортом, доступным для экскурсий, были лошади, ослы и мулы [2]. На основе туристических прогулок возле туристических баз было сформировано экскурсионное движение. Во времена советской власти в 1921 г. целевыми туристами были люди с достатком, количество которых оставляло желать лучшего [3].

Новый Афон - следующий населенный пункт, который обращает на себя внимание. Большие суммы денежных средств выделялись на рекламу и поддержание Новоафонского монастыря. Новый Афон становится центром духовенства Республики Абхазия.

20 марта 1919 г. В.И. Лениным был подписан декрет «О лечебных местах общегосударственного характера», 11 июня 1921 г. был издан третий декрет, за подписью В.И.Ленина, который был направлен на создание условий, необходимых для массового курортного лечения трудящихся. Именно Ленинские декреты предопределили дальнейшие пути развития курортного дела и принципы организации медицинского обслуживания больных в санаториях и на курортах. В марте 1921 г. специально созданная комиссия объявила о национализации 41 частного владения [4]. В Сухуме было национализировано 26 и муниципализировано 92 частных владения, в том числе 24 дачи. В конце 1921 г. города курорты Абхазии стали функционировать. С 1921 г. объекты туризма и отдыха становятся доступными для трудящихся масс и военнослужащих, проходивших в этих местах реабилитационное лечение, по итогу к 1922 г. удалось развернуть 150 мест.

В это время курортами Абхазии ведал отдел лечебных местностей Наркомздрава республики, который разделил на 2 курортных района - Сухумский и Гагринский. Так же в августе 1922 г. создали Абхазское научное общество (АбНО) для исследования исторических и природных достопримечательностей. При АбНО сформировали отдел, который занимался экскурсионной работой, возглавляемый Басария С.П. В Сухуме находилось экскурсионное бюро Главполипросвета Абхазии, которое руководило экскурсионными работами на территории республики.
Главным событием произошедшим в 1928 г. для Абхазии стало создание общества пролетарского туризма (ОПТ). Основную помощь ОПТ в организации туристических объектов брали на себя органы республики. Общество создало маршрут в район озера Рица, который был сокращен [4]. С 1929 г. Интурист включает Абхазию в число объектов посещения иностранных туристов и зарубежных рабочих делегаций. В 1931 г. Всесоюзное ОПТ было преобразовано в ВОПТ и экскурсии. Массовое туристическое движение началось с создания АбхазОПТЭ. Начали разрабатываться новые туристические маршруты, соответствующие всем потребностям туристов, расширяется материально-техническая база туризма. Санаторно-курортное строительство активно начало развиваться в 1932-1940 гг. На базе Новоафонского монастыря, после передачи в курортное управление, был построен санаторий на 500 мест. В республике стало улучшаться качество обслуживания, стали обустраиваться кабинеты лечения больных. В каждом городе Абхазии стали появляться дома отдыха и санатории [4].

Во время Великой Отечественной Войны большое число здравниц было передано войсковым частям для организации госпиталей. Значительные вложения требовались для восстановления объектов, задействованных во времена военных действий. В 1944 г. было принято решение «Об оказании помощи Совнаркому Абхазской АССР в производстве ремонта санаториев и домов отдыха». В 1945 г. начался послевоенный этап развития курортов. В период 1944-1959 гг. было выделено 400 млн. рублей на развитие курортов Республики Абхазия. В Сухуми в 1956 г. было сформировано агентство ВАО (Всесоюзное акционерное общество) «Интурист», позже, спустя 5 лет оно было преобразовано в отделение ВАО «Интурист» по Абхазской АССР [5]. Через два года, в 1958 г. создается Общество охраны памятников культуры, которое включает в себя научные организации и центры. Абхазский совет своими силами создает выставочные музеи в Пицунде и Гагре, издает рекламные буклеты, путеводители и другую справочную литературу, как для туристов, так и для местного населения [5].

Дает начало новый этап в жизни курортов в 1960 г. Формируется Абхазский областной совет по туризму в Сухуми, приступивший к внутреннему руководству туристической и экскурсион- 
ной работами. Начинаются постройки нового типа санаториев, которые соответствуют всем требованиям, выполнены в современной архитектурной постройке и оснащены современным на тот момент оборудованием [6].

В период 1960-1980 гг. в Республике Абхазия был туристический взрыв. Большие суммы денежных средства были выделены государством и ведомственными объединениями на постройку санаториев, домов отдыха и пансионатов. Этот период запомнился тем, что было введено 59 объектов туризма в эксплуатацию (более 15000 койко-мест). К 1980 г. Сухум посетило более 61 тыс. туристов из 24 стран, в порту побывало тридцать пять круизных судов [1].

В период 1980-1990 гг. строительство курортов постепенно начало сокращаться. K началу 1990x годов в Абхазии существовало 125 объектов туризма с общим количеством койко-мест 34502. Санаторно-курортные объекты приходят в упадок. Стоит выделить интересную закономерность: количество санаторно-курортных объектов с северо-запада на юго-восток резко сокращается. Основная часть объектов -75 , располагалась на северо-западе Абхазии, а именно в Гудаутском и Гагрском районах [3].

Объяснить такую тенденцию можно тремя факторами:

1. Исторический - удивительная и многолетняя история региона, насчитывающая более 3 тыс. лет, расположение важных культурных и религиозных памятников архитектуры и природы на северо-западе Абхазии.

2. Геополитический - близкое расположение западной Абхазии с границей России, которое предрешило постройку большинства санаторно-курортных объектов именно в западной части республики.

3. Природный - Западная Абхазия славится удивительным микроклиматом (Гагра, Новый Афон), близким расположением горных систем (Гагрский, Бзыбский хребет), колоритностью ландшафтов, главными экскурсионными объектами (оз. Рица, Ново-Афонская пещера) [6].

Вплоть до 1992 г. формированием туристической отрасли руководило несколько организаций: Абхазский Облсовет по управлению курортами и профсоюзами; Совет по туризму и экскурсиям; Бюро молодёжного туризма «Спутник»; ВАО «Интурист»; турбазы министерства обороны; Управление туризма МО СССР.

Республика Абхазия - это независимое госу- дарство, которое признано немногими странами, которыми являются - члены Организации Объединенных Наций (Россия, Венесуэла, Науру, Южная Осетия, Никарагуа, Народная Корейская Республика и ПМР) [5].

По настоящее время большая часть государств относит Республику Абхазию к Грузии, что является ошибочным. Необходимо затронуть факт того, что Абхазия имеет собственное правительство, свои вооруженные силы, силы безопасности и правопорядка, и при этом государство не контролируется грузинскими властями.

Большая помощь была оказана Россией Абхазии после войны с Грузией. Республике Абхазия необходима поддержка российского правительства и по настоящее время, по-прежнему Абхазия пребывает в таком же неопределенном статусе как Южная Осетия и Косово [6].

Российским туристам въезд на территорию Абхазии не представляет сложностей, он бесплатен и виза не требуется, так как Россия признала Республику Абхазия независимым государством. Остается закрытой граница со стороны Грузии, через нее невозможно пройти без особого разрешения. Пройти пограничный пост можно как пешком, так и на транспорте.

Таким образом, туризм - главная отрасль экономики Абхазии, приносящая республике немалые инвестиционные потоки. Но стоит выделить ряд проблем, останавливающих дальнейшее развитие туризма в регионе.

Начав разговор об Абхазии, как о регионе со слаборазвитой экономикой, не стоит забывать грузино-абхазскую войну 1992-1993 годов. Эта кровопролитная война сыграла огромное значение в развитии страны. Результатом военного конфликта государств, Республике Абхазия был нанесен колоссальный экономический ушерб, насчитывавший более 11 млрд. долларов США. Более 250 тысяч человек (в основном грузины) были вынуждены оставить страну [6]. Наблюдался рост безработицы в период послевоенного времени. Отрасль сельского хозяйства, как главная отрасль экономики республики находилась в упадке, не было ни высоких урожаев, ни экспорта востребованной сельскохозяйственной культуры. Комбинаты и производства разрушены и разграблены. Вынуждено должны были искать работу за рубежом квалифицированные специалисты. Колоссальные потери были в отрасли туризма, которая была главным источником 
поступления денежных средств в экономику. Разрушены санатории и гостиницы. Восстановление частного сектора своими силами затруднительно, а от государства поддержка не поступала. Спустя еще долгое время Республика Абхазия была в послевоенном состоянии [6].

Постепенно стали нормализоваться отношения между Россией и Абхазией в сферах хозяйства и транспорта. Уже 4 апреля 1994 года грузинской и абхазской сторонами в Москве было подписано «Заявление о мерах по политическому урегулированию грузино-абхазского конфликта». Основываясь на данном заявлении, на территории Республики Абхазия была построена российская военная база, в то же время российские пограничники приводят к действию охрану границ республики с Грузией. Вследствие чего при помощи Российского государства возвели и оживили железную и автомобильную дорогу, была доставлена техника для освобождения городов и сел, кроме того была освобождена береговая зона от разбитых военных машин [5]. Спустя 10 лет в 2004 году восстановили автобусное сообщение между станциями городов Сочи в России и Сухум в Абхазии. С помощью колоссальной поддержки Российского правительства было проведено в исполнение укрепление Российско-Абхазской границы, что явилось следствием усиления дружеских отношений между двумя государствами [5].

В Республике Абхазия сохраняется единственная территория, контролируемая грузинскими властями, - это верхняя часть Кодорского ущелья. В 2008 году, в ходе, так называемой «войны 5 дней» - вооруженного южноосетинскогрузинского конфликта, власти России совместно с властями Абхазии в ответ на нападение грузинской армии на Цхинвал, пришли к выводу принять решение о боевых действиях против грузинской армии. В ходе операции российских и абхазских войск вся территория Абхазии была освобождена от грузинских войск и перешла под абхазский контроль. Позднее Абхазия была признана Россией в качестве независимого государства [8].

Республика Абхазия - частично признанное государство, легитимность которого признаётся 5 государствами-членами ООН, большинство государств-членов ООН считает страну частью Грузии, согласно административно-территориальному делению которой она является Автономной Республикой Абхазия.
После окончательного разрешения вопроса о самостоятельности Республики Абхазии, поток туристов на абхазский берег Черного моря резко увеличился. Но здесь теперь встает один из глобальных вопросов послевоенного времени безопасность туристов.

Каждый турист заботится о своей жизни в месте пребывания. Главным фактором при выборе места проведения отдыха, конечно, является безопасность. Рассмотрев уровень безопасности в Абхазии, можно сказать, что необходимо создать туристическую милицию, которая будет регулировать вопросы туристов на отдыхе. Проводить беседы с местным населением, о том, что туристы оказывают положительный эффект на развитие туризма и на экономику в целом, и для поддержания обстановки дружелюбия необходимо уважительно относится к каждому приезжающему на отдых туристу.

В 2014 году в ходе своего двухдневного визита в Абхазию Президент России В. В. Путин особо упомянул проблемы безопасности. «Мы надежно гарантируем безопасность и самостоятельность Абхазии, ее независимость. Очень рассчитываю, надеюсь на то, что эта совместная работа будет повышать уровень безопасности пребывающих здесь туристов» [9].

Рассматривая далее проблемы туризма как отрасли экономики республики, нельзя не упомянуть о достаточно узком предложении и разнообразии выбора для туриста. Все делается по одному шаблону, в маршруты турфирм зачастую включают одни и те же туры. Отсутствуют разнообразные туристические маршруты, которые были бы уникальны в своём роде и отвечали бы всем требованиям туристов.

Абхазия заявляет о себе, как о туристической стране со своей древней историей и культурой. Но любая страна может предложить такой же набор туристических услуг. В республике отсутствует уникальное предложение, которое смогло бы затмить собой предложения других стран с такими же природными ресурсами. Популярность направления туризма в Абхазии выйдет на новый уровень, как только регулирующие туризм органы смогут выделить и разрекламировать уникальные преимущества региона. На данный момент весь отдых приводит к примитивному досугу и заурядным развлечениям. Основной поток туристов приходится на Россию, и туристы из России выбирают Абхазию, как уже знакомое место отдыха, так скажем «место по 
старой памяти», с прекрасной природой, чистым морем, дешевизной путешествия. Но выбирая только море, турист вряд ли задержится в месте пребывания, именно поэтому необходимо разнообразить жизнь туриста, чтобы поездка запомнилась ему, и каждый раз он приезжал бы не только за чистым морем, но и за увлекательными рассказами о жизни и быте народа Абхазии, о его прекрасных окрестностях, уникальной природе [8].

K основным проблемам, препятствующим развитию туризма, стоит отнести неразвитость транспортной инфраструктуры, систем связи, информационную осведомленность населения, низкий уровень сервиса, безопасность, неактуальные туристические маршруты, безвизовый режим.

Инвесторы со скептицизмом относятся к вложению в регион. В связи с криминогенной обстановкой, вкладывая крупный капитал в туризм, инвесторы опасаются за спокойствие работы. Такое представление возникает не спроста, в республике не решены проблемы с обеспечением безопасности, отсутствует система страхования, гость страны не чувствует себя защищенным.

Рассуждая на тему направлений туризма, успехи здесь есть, но в связи с большим потоком туристов, выбирающих именно направления пляжного туризма, роль других немаловажных видов уходит на второй план. В регионе есть перспективы для развития культурно-познавательного, паломнического, гастрономического, а главное экологического туризма, которые в свою очередь требуют развития и немалых средств [9].

Для полноценного развития туристической отрасли в Абхазии, необходим свой бренд, который должен соответствовать международным стандартам качества обслуживания и включать в себя широкое и богатое содержание.

Удивительная природа республики - это тот ресурс, с помощью которого можно развивать туризм. Прекрасные горы Абхазии занимают три четверти площади республики, удивительное чистое море, горные быстрые реки - всё это может послужить базисом для развития здесь экстремального и развлекательного туризма.

Уровень сервиса недостаточно развит в связи с неквалифицированностью кадров. Необхо- димо создавать специальности по направлениям туризма и гостиничного сервиса, обучая по современным методикам в местных учебных заведениях. Привлекать молодых специалистов из-за рубежа, создавая для них хорошие условия работы. Проводить тренинги и различные обучающие программы для улучшения работы персонала. Так же персонал должен владеть иностранными языками, для комфортного пребывания туристов из разных стран.

Республика Абхазия заключила соглашение на безвизовый въезд лишь с малым количеством стран, что, тем не менее, значительно облегчает въезд в страну. Для других стран происходит оформление визы на определенные сроки, количества дней на отдыхе, групповая или индивидуальная, с целью поездки и количеством посещений.

Развитие транспортного сектора в настоящее время ухудшается, внутри страны действует маршрутное такси, как общественный транспорт. Плата за проезд вполне приемлема, можно сказать дешевая. Аэропорт не функционирует, он принимает лишь гражданские самолеты, совершаемые Миссией $\mathrm{OOH}$ и российскими миротворцами, а железнодорожным транспортом сложно добираться из большинства стран.

В стране действует роуминг, интернет ловит недостаточно хорошо, чтобы можно было спокойно перемещаться и проводить время в интернете. Но в туристических местах, отелях, ресторанах, кафе можно воспользоваться WI-FI [11].

Важной проблемой, которую не стоит оставлять без внимания является информация. Население других стран мало осведомлено не только о туризме в Абхазии, но и о самой республике в целом. Информации в интернете очень много, но в основном это устаревшие данные о туристических маршрутах, местах размещения и самой отрасли туризма. В настоящее время информацию можно назвать ведущим фактором развития туризма в регионе. Публикации статей в печатных изданиях и интернет-ресурсах, видеоролики, красочные и впечатляющие фотографии - всё это должно обновляться ежемесячно. Каждый турист, захотевший посетить Абхазию, должен быть осведомлен об обстановке в Республике на настоящий момент. 


\section{Библиографический список}

1. Аджинджал И. А. Из этнографии Абхазии. Сухуми: Алашара, 2015.-121с.

2. Анчабадзе 3. В. История и культура древней Абхазии.- М.: Наука, 2016. - 175 с.

3. Бгажба О.Х., Лакоба С. З. История Абхазии с древнейших времен до наших дней. Сухум: Алашарбага, 2014.245 c.

4. Григолия А.Л. Курортные богатства Абхазии. Л., 2014.-147с. 18.Григолия А. Л. Гагрская группа курортов. М., 2015.-89c.

5. Лашхия Ш. В. Абхазская АССР: Природные ресурсы и хозяйственная практика.- Тбилиси, 2016. - 114 с.

6. Фейзба Я.Р., Шамба О. Б. Национальная экономика Абхазии. Сухум, 2014.- 185 с.

7. Стратегия социально-экономического развития Республики Абхазия до 2025 г. // Центр стратегических исследования при президенте Республики Абхазия. Сухум, 2015.

8. Информационный сайт Абхазии [Электронный ресурс]: http://www.sukhumkurort.ru/2011-06-12-13-3906.html. (Дата обращения 02.12.2020).

9. Российско-абхазский деловой совет, материалы по статистике Абхазии [Электронный ресурс]: http:// rosabhsovet.ru/economy.html. (Дата обращения 10.12.2020).

10. Таишева Г.Р., Нуримухаметов Р. М. и др. Состояние и перспективы обеспечения экономической безопасности, развития маркетинга и туризма в России// Казань.-Изд-во «Познание». 2011.-216с.

11. Agumaa A. The architecture of Suhum: late 19th and early 20th century. Suhum, 2016.

12. Douglas W. Freshfield The exploration of the Caucasus. Volume II. London \& New York, 2014. 